\title{
THE CONFEDERACY AND THE DECLARATION OF PARIS
}

\author{
Lrencot, Ulillian Ferry
}

REPRINTED FROM THE

\section{American Gifistorical geneview}

VOL. XXIII, NO. 4 



\section{The Confederacy and the Declaration of Paris.}

For the following documents from the papers of the late William Henry Trescot, chiefly memoranda in his own handwriting, nearly contemporary with the events which he describes, the readers of the Review are indebted to his son, Mr. Edward A. Trescot, of Pendleton, South Carolina, who contributes the following prefatory note:

Mr. Trescot died in May, I898. Among his papers were found the following. As the negotiations to which they refer are a part of the history of that period, I do not believe that their publication would be contrary to any wish or desire on his part. Furthermore, by their publication in the American Historical Rcvicw they will be preserved in a more permanent form and be accessible to any one who may feel interested in the subject.

Mr. Trescot was appointed Assistant Secretary of State by President Buchanan June 8, I86o. Because of the absence and illness of Gen. Lewis Cass the Secretary, he was made Secretary under warrant by the President, June 20, and served as such until the return of Gen. Cass late in the fall.

Mr. Trescot was a South Carolinian and as his state was on the eve of secession, he felt it his duty to resign and did so on December Io, I86o. By the early part of I86I he had returned to his home ir. Charleston, so that, when Mr. Bunch and Mons. Belligny, the British and French consuls respectively at Charleston, urged upon him on July 19, I86r, that he induce the Confederate States government to adhere to certain articles of the Declaration of Paris, Mr. Trescot was, and had been for nearly eight months, a private citizen.

Prior to Mr. Trescot's appointment as Assistant Secretary of State, he was secretary of legation at London. After the close of the Civil War, during which he had served on the staff of Gen. R. S. Ripley, he returned to Washington and as the executive agent of the state succeeded in bringing about a better understanding between the state and federal governments as to the enforcement of the Reconstruction laws and not only secured the release of much of the state's property but that of many individuals, which had been seized by the federal authorities. He subsequently served the United States in a varied series of diplomatic appointments.

Mr. Trescot's papers on the subject include also copies of Lord John Russell's instructions of May I7 (18), I86I, to Lord Lyons at Washington, of the latter's instructions of July 5 to Robert Bunch, and of Bunch's dispatch of August 16 to Lord Lyons, but these have been several times printed, and are not here repeated. 
Foot-note references on pages 75 and 76 of the Case of the United States in the Geneva Arbitration to "MS. document in the Department of State" warrant the inference that a memorandum by Mr. Trescot, on the same transactions as those described in the following papers, exists in the archives of that department, but, with a reference so little specific, it cannot at present be found.

I. Memorandum of a Conversation between Mr. Bunch, H. B. M. Consul, and Mons. Belligny, the Consul of the Emperor of France, and Mr. Trescot. ${ }^{1}$

On Friday the igth July I86I, Mr. Bunch called upon me and after enquiring what were my relations with the Administration and being informed that while I could not say that I had any relations with it in a public sense, my personal relations with its head were of the most friendly description and that I had enjoyed opportunities of very full consultation with Mr. Davis during the existence of the old Government, said, Mons. B. and myself have received today despatches from our respective Governments identical in language and of the most delicate and important character. We are instructed to put ourselves in connection with the Government at Richmond but to do so through an intermediary. I cannot explain more fully except in the presence of my colleague but we have after consultation determined to ask you to meet us in order that we may submit these instructions to you and will ask you if you can do so to become the channel of communication between us and the Government at Richmond. Mr. Bunch expressed his conviction of the very great significance and importance of this step and indicated that the general purpose of the Instructions was to obtain the adhesion of the Confederate Government to the 2 and 3 articles of the Declaration of the Paris Conference. At 8 o'clock that evening I met Mr. Bunch, Mr. Belligny and Mons. St. André, the intended successor of Mr. Belligny. ${ }^{2}$

Mr. Bunch read me Lord John Russels Despatch of 17 th May, ${ }^{3} \quad$ Lord

1 See J. B. Moore, International Arbitrations, I. 564-565; also F. Bancroft, Life of Sezvard, II. 197-198, based partly on conversation with Mr. Trescot. Robert Bunch was British consul at Charleston from ${ }_{1} 853$ to 1863 . See M. L. Bonhan, jr., The British Consuls in the Confederacy (New York, 191 I), pp. 20-47, 5I-60, I I2-I2I; and Moore, International Arbitrations, II. I426. M. de Belligny Ste. Croix was French consul at Charleston from 1856 to 1861 . In these texts, abbreviations for "Confederate" and "Government" have been expanded.

2 M. Durant de St. André subsequently acted as consul without exequatur from either the Confederate or the United States government. Bonham, pp. 219,221 .

3 Printed, with the date May I8, in Correspondence relating to the Overtures addressed to the Contending Parties in the United States, with a View to their Adhesion to the Principles of Maritime Law, as laid down by the Congress of Paris [Cd. 29I1], pp. 4-6 (Sessional Papers, I862, LXII. 540-542), in British and Foreign State Papers, LV. 550-554, and in U. S. Diplomatic Correstondence, 186r, I. 131-133. See also Lord Newton's Lord Lyons, I. 44, letter of Lyons to Russell, June io, I86 I. 
Lyons official letter of the 5 th $\mathrm{July},{ }^{4}$ and a long private letter of Lord Lyons on the same subject, adding " and now you know all that I know myself". Mr. Belligny handed me the Instructions of Mons. Thouvenel and M. Merciers ${ }^{5}$ letter saying at the same time, they are transcripts indeed translations of those just read by Mr. Bunch, which I assured him was enough without his reading them to me.

It was clear that the two Governments wished an official act of adhesion, to obtain which the two Consuls were authorised "to negotiate" informally, but they were not to go to Richmond and the negotiation was to be carried on by an intermediary. I observed that admitting the importance of the communication and supposing a disposition to accede to it, were they prepared to receive an official act which should be based upon their request, thus giving to the Confederate Government the advantage before the world of stich an implied recognition as this would afford. To this they objected. They wished "a spontaneous" declaration on the part of the Confederate Government. I replied, I do not see how you can ask this. The Conference of Paris laid down certain principles to which it asked the adhesion of "the pozvers" of the world and in Ld. J. R. despatch you distinctly ask the U. S. to accede. Now can the Confederate Government, with self respect, before you recognise, volunteer an adhesion and thus intrude among nations which refuse them recognition? Might not such "an official act" be repudiated by such states (Russia, Prussia, etc.) who are not partics to this application? It seems to me but common justice that if "the official act" is granted the Confederate Government shall by its language vindicate itself from any such charge as I have indicated.

They replied, that to make this request the declared basis of the Act would be to proclaim this negotiation, and the intense jealousy of the U. S. was such that this would be followed by the revocation of their exequaturs and, unless disavowed by their Governments. by the dismissal of Lord Lyons and Mons. Mercier from Vashington. That this was just what they wished to avoid and that while they-the Consuls-were free to say that they could only look upon this step as the initiative towards a recognition, yet the object of their Governments being to reach that recognition gradually so as not to give good ground for a breach, this indirect way was absolutely necessary. That this was an unparallelled step in advance toward a belligerent not yet recognised and it was, they thought, of immense importance to conciliate these powers in view of this advance, without too much strictness as to form. etc. etc.

I said, I admit, if this adrance were to be made public, we might afford to go far to meet it, but the secrecy which you make the essential of your negotiation, deprives the Confederate Government of the very advantage which you urge upon them as a reason for acceptance. Such a negotiation would be recognition and the Confederate Government might be willing to make such a concession therefor, but you do not

4 Printed in Correspondence, etc., p. I3 (Sessional Papers, 1862, LXII. 549). in British and Forcign State Papers, LV. 564-565, in Mountagne Bernard, Neutrality of Great Britain, pp. I $\mathrm{S}_{\mathrm{I}-\mathrm{I}} \mathrm{S}_{2}$, and in Correspondence concerning Claims against Great Britain, I. 123-124.

5 Thouvenel, French minister of foreign affairs, 1860-1862; Mercier, French minister to the United States, $1860-1863$. 
mean it as recognition altho you believe it will lead to it. They said frankly they could make no pledges as to any consequences to result, altho they believed, indeed had no doubt that the consequences would be most agreeable and beneficial to the Confederate Government.

After discussing this matter at some length I said, You cannot expect that the Confederate Government should not derive all the benefit it can from this move consistent with good faith to you. All that you can fairly ask is that "the official act" you desire shall not commit your Governments nor compromise you. Suppose therefore that the act should recite that Whereas the powers of Europe have publicly recognised the Confederate States in the character of Belligerents and whereas this Government has reason to know that it would be acceptable to the said powers, that as Belligerents we should adhere to the Articles of the Treaty of Paris, etc., etc., therefore, satisfied that a more formal recognition shall be the result of better knowledge, etc., we in deference to these wishes, etc., do adhere, etc., etc.,-would that satisfy you? Mr. Bunch replied, Certainly I think so. Nobody has a right to say that you received your knowledge throngh us. It might very well be supposed that you received it through your Commissioners in Europe. All we have a right to ask is that you shall not give publicity to this negotiation-that we nor our Governments should be upon the record. As to the truth, all interested to know will soon find out, but as long as on your part there is no avowal of it, you will have kept faith with us. And in this Mr. B. seemed to acquiesce. Another point was also discussed. The Consuls having asked for "the official act", that act was not to be submitted to them for approval, unless the Government so desired. Their request being granted the mode was to be left to the President. I next asked, Suppose the Confederate Government do not take the view which we have been examining hithertosuppose they think that such an adrance as you have made is not of itself sufficient to warrant such a concession, but that the concession is large enough to justify the demand of an equivalent-are you authorised to negotiate on such a basis? They said, No. Any reply made to their request they would certainly receive and transmit, but they did not consider themselves as negotiators on any extended scale. Their Governments had done a very unusual thing in making such a request and having asked they would simply convey the answer. I said I thonght their instructions implied more than that, and that the request of the Government, however unusual, once made drew with it certain consequences, but that of course they were the only interpreters of their own authority. (In my opinion any such proposition would be humiliative [?] to the Ministers at Washington.)

There was then a good deal of general conversation as to the policy of the Confederate Government's accepting frankly and cheerfully the proposition, to which of course I listened with attention but I did not think it judicious to express any opinion.

I then said. This you mean as a strictly confidential communication. I must therefore before convering your proposition to the President inform him that my communication is confidential. Suppose he says he cannot receive any such confidence-that he will not consent to hear any proposition which he cannot communicate, whether after hearing it he may be willing to treat it as confidential or not. On this head your 
instructions must be positive. After discussion they decided if the President refuses to receive it confidentially-you must not make it. Of course confidentially does not exclude his responsible advisers. I next asked, Suppose him willing to receive it, what evidence do you give me to satisfy him, first, that I am authorised to speak for you, secondly, that you are authorised to speak for your Governments. This led to a good deal of discussion but I finally said it was impossible simply for me to act as a volunteer in this matter, that the President might very well believe that I spoke for them, and what they said, but that he must have some proof of their authority to speak at all. That so grave a communication could not be received on the personal character of anybody, however respectable, and in their cases especially, as they had, so far as the President was concerned, no official character to give presumption to their representations. It was therefore agreed that I should take on Lord I. R.'s Instructions and Lord Lyons letter.

In conclusion I said I understood this whole matter thus-

I am to inform the President that I am the bearer of an importani communication from you which is to be made to him confidentially. If he is willing to receive it confidentially I will submit it. If not I will not make it.

Having submitted it I am no longer responsible. It is in the discretion of the President, not mine.

The proposition I am not understood as approving or disapproving and am perfectly free to advise its rejection or its acceptance as I think right.

\section{II. [Memorandum CONTINUED.]}

I left Charleston on Saturday the

6 with Lord I. R's despatch, Lord Lyons letter and a Mem. of the conversation between the Consuls and myself. I reached Richmond on Monday and found that the President had gone to Manassas ${ }^{7}$ and was not expected [to] return for some days. After some reflection I called upon Mr. Hunter ${ }^{8}$ and consulted him as to the propriety of waiting the P.'s return or going on to him. Mr. H. thought the matter so important that he advised me to go on at once and for that purpose procured a Permit from Gen. Lee. I left for Manassas the next day but at Gordonsville met the down train with the wounded on its way to Richmond. Finding that the President was on board I returned and the next day communicated to him the object of my visit and the papers connected therewith, stating the character of nny conversation as noted in the Memorandum. A cabinet meeting was called and after a decision was reached, the subject was referred to Mr. Hunter, who had just been appointed Secretary of State in place of Mr. Toombs-for conference or rather communication with me. The substance of the several communications with $\mathrm{Mr}$.

Gaturday, July 20, $186 \mathrm{r}$.

$7 \mathrm{Mr}$. Davis went to Manassas on Sunday, July 21 , the day of the battle, and returned on Tuesday, July 23. Davis, Rise and Fall of the Confederate Gor'ernment, I. $348,359,361$.

8 Robert M. T. Hunter was at this time a delegate from Virginia in the Provisional Congress of the Confederate States. On July 24 he was nominated, and on July 25 confirmed, as Secretary of State, in place of Robert Toombs. Journal of the Confederate Congress, I. 282. 
Hunter I reduced to the shape of a Mem. to serve for my instruction. And upon learning from him, that the Resolutions adopted by the President had been referred to the Comm. of Foreign Affairs, ${ }^{9}$ I returned home. These resolutions when passed and approved were sent me in copy from the State Dep. and given to Mr. Bunch and Mons. Belligny with such explanation as was in conformity with the Mem. of Instructions. ${ }^{10}$

There was a slight delay in the passage of the resolutions as the President desired a change in the form and phraseology of the first set-a change which was a very great improvement, but it was not of consequence enough to be talked about. ${ }^{11}$

The Mem. of Instruction does not contain one branch of the subject, viz.- the desire that the C. S. should acknowledge their responsibility for the acts of their Privateers should they violate the limits of International law. I was instructed not to refer to this subject unless specially asked by the Consuls and then simply to furnish them with copies of the Act and Instructions regarding Privateers, say that these were within the principles of recognised law and that the C. S. could give no other assurance than their acts and character that the obligations of International law would be discharged.

August I 7 th, I86r.

IV. H. T.

III. ${ }^{12}$

The informal communication from the Consuls of England and France has been received by the Confederate Government. The President regrets that a communication of such grave importance should be made in so irregular a manner, as the necessity for such a communication is in itself the strongest evidence of the propriety of instituting between the Powers of Europe and the Confederate States, regular and established regulations [relations]. For it is clear that if the existence of the new Government creates new and important interests, their adjustment in an amicable spirit and for mutual benefit is of far too great importance to be entrusted to secret and unrecognised agents. In any such negotiation the obligations assumed have an unequal character and want that essential of official responsibility which gives force to the ordinary action of Governments. The President is therefore very unwilling to encourage a mode of proceeding which is not only wanting in that respect to which he feels the Government of the Confederate States

9 Introduced in Congress by Hunter on July 30 , referred that day to the committee named, reported August 2, passed August 8 ; vote reconsidered Au. gust 9, and a substitute, also introduced by Hunter, passed August 13. Ibid., I. $294,310,326,33 \mathrm{I}, 34 \mathrm{I}$.

10 A letter from Mr. Trescot to Mr. Hunter, dated August 3, after his return to Charleston, and describing the verbal report he had made to the two consuls, is printed in Richardson, Compilation of the Messages and Papers of the Confederacy, II. 54-56.

11 See note I 3 , post.

12 This paper is endorsed: "Summary in shape of Instructions of Conversation with Mr Hunter. Read to Mr H. W. H. T. No. 4." “No. , " in Mr. Trescot's series is no. I., above; “No. 2 " is our II.; "No. 3 " is a copy of Lord Lyons's dispatch to Bunch, July 5, enclosing that of Russell to Lyons, May 17(18). 
to be fully entitled but which is in his opinion calculated rather to embarrass than to assist the final adjustment of important questions. But while impressed with this conviction the President will not refuse to receive as information a communication of such a nature as that submitted to him and to respond to it in so far as its subject matter commends itself to his judgment and requires only on his part the exercise of a discretion perfectly free and governed entirely by his sense of the interest and dignity of his own Government.

And the President feels also that even supposing the character of this communication to be such as to justify a disregard of those formalities which guard the correspondence between Nations whose existence is fully recognised, yet he cannot but think that those representatives of the Confederate States at present in Europe with the authority of the Government but as yet unrecognised by the European Powers, would have been the most natural channels through which it should have been made, as the communication through them in their present character would not have further conmitted the Governments of England and France to any greater extent than the mode which has been selected in this instance.

With regard to the Proposition itself, the Presiclent does not feel called upon to declare his adhesion to the Articles of the Treaty of Paris by any official act which shall recognise a public instrument to which his Government was not a party and to which he has not been invited to accede in the only way which would justify his acceptance, viz., as a recognised Government.

But the President does feel not merely a willingness bit an anxiety that the position assumed by the Confederate States, in claiming an independent existence, should not be misunderstood, and has not the slightest hesitation in declaring in the plainest manner, the determination of his Government to adhere with scrupulous fidelity to those laws which regulate the international intercourse of the world and determine their relations of peace and war. Believing that the principles laid down in the 2nd, 3 rd and 4 th Articles of the Conference of Paris are founded in Justice and well calculated to confine the painful consequences of a state of war within the narrowest limits, the President will cheerfully make known by such an official act as is in conformity with the requirement of the Constitution, that the Confederate States accept these principles as the rules of their conduct, and this without reference to the Declaration of Paris but upon the conviction that they are now the recognised law of that family of nations into which the Confederate States claim to enter on a footing of perfect equality.

In so far conforming to the wishes of the Governments of England and France the President expresses the hope that the same anxiety manifested by these Governments for the adhesion of the Confederate States to the 2 and 3 Articles of the Declaration, will be exhibited in watching the exact fulfillment of the condition of the 4 th Article in the war at present existing between the U. S. and the C. S. For the three principles are but parts of one system and that system is only valuable as they are all put in force and carefully observed, and the Governments of England and France will not in his opinion be carrying out the spirit of the communication which they have just made if they continue to submit to the open and continued violation of this principle which has 
marked the conduct of the U. S. from the declaration of the existing blockade until the present moment.

The President also thinks that in face of the willingness of the C. S. to accept the principle of Free ships, free goods-a principle which in its practical working must confer great advantages upon the mercantile marine of England and France, he has a right to expect that the neutrality of these powers will not be allowed by an apparent impartiality to interfere with the acts of legitimate hostility which the C. S. are entitled to use as belligerents, and he cannot but think that the refusal to allow the C. S. to use the ports of these countries for the purpose of carrying in and condemning prizes is, with apparent impartiality, an act which discriminates largely and unjustly against the interests of the C. S.

In conclusion the President feels that the Confederate States have assumed a position strictly in conformity with those principles of Constitutional right recognised in the great instrument which was once the common guardian of the two nations now at war, that in all the proceedings which have marked the progress of this controversy, his Government has maintained unshaken the supremacy of law and order and have administered without disturbance the great functions which support the social, industrial and political life of a nation, that in the unrighteous invasion to which they have been subjected, the Govt. has not only held its own but has achieved such victory as places the reduction of the country without the pale of possibility.

Feeling this, he can wait with patience and confidence the time when the nations of the world will recognise the truth and do full justice both to the motives and the acts of his Government.

But knowing that the interests of Europe are deeply concerned in the progress and result of the conflict he can only hope that an intelligent examination of these interests will convince the statesmen to whose charge they are committed, that it is best for all the nations of Europe to recognise at the earliest moment the fact which has established itself without their recognition-that the Confederate States are and of right ought to be a free and independent nation-and thus to put the vast industrial, commercial and moral interests which are concerned, under the charge and guardianship of recognised and recognizable national representatives.

This Memorandum was read by me to Mr. Hunter that it might be considered as an Instruction as to the nature of the conversation which I should hold with the Consuls on my return. It was slightly -modified in a further conversation by the determination to refer to the Declaration of Paris in the Preamble of the resolutions as containing the principles declared in a brief form and as evidence of their being the accepted modern law of nations.

\section{Newspaper Clipping. ${ }^{13}$}

W. H. T.

Our Special Despatches from Richmond: From our own Correspondent. RichMond, August 8th.-The following important resolution was adopted to-day by the Congress of the Confederate States:

13 This is from the Charleston Mercury of August 9. It preserves the form in which the resolution was originally passed (see note 9), but which is not 
A Resolution Touching Points of Maritime Law, Decided by the Congress of Paris of 1856 .

Whereas, it has been found that the uncertainty of maritime law, in time of War, has given rise to differences of opinion between neutrals and belligerents, which may occasion serious misunderstandings, and even conflicts; and whereas, the Plenipotentiaries of Great Britain, France, Austria, Prussia, Sardinia and Russia, at the Congress of Paris, of $185^{6}$, established an uniform doctrine on this subject, to which they invited the adherence of the nations of the world, which is as follows:

I. That privateering is and remains abolished;

2. That the neutral flag covers the enemy's goods, with the exception of goods contraband of war;

3. That nettral goods, with the exception of contraband of war, are not liable to capture under the enemy's flag; and

4. That blockades, in order to be binding, must be effective; that is to say, maintained by a force sufficient really to prevent access to the coast of the enemy,

And whereas, it is desirable that the Confederate States of America shall assume a definite position on so important a point, now, therefore,

$B_{e}$ it Resolved, That the Congress of the Confederate States of America accept the 2 nd, $3 \mathrm{rd}$, and 4 th clauses of the above cited declaration, and decline to assent to the Ist clause thereof.

\section{Telegram.}

William Henry Trescot

Richmond, [August] io, i86I.

Charleston, S. C.

Resolutions passed but sent back to Congress on account of Preamble. The principles will be affirmed in some shape. When passed I will send them to you.

VI. LetTER. ${ }^{14}$

R. M. T. Hunter.

\section{Confederate States of America. Department of State.}

My dcar Trescot:

Richmond, August I4th, I86I.

Mr. Hunter requests me to send you the enclosed. He has received printed in the Journal. The resolutions as finally passed (Journal, I. 341) differ from the above document chiefly in transferring the articles of the Declaration of Paris from the preamble to the body of the resolutions, and in making more explieit the Confederate declaration as to privateering. It will be remembered that the sessions of the Provisional Congress were secret. The Richmond Examiner of August 12 says that the resolutions, then under discussion, were drafted by Hunter; on August 14 , presenting their text in the form in which they passed, it alludes to an incorrect version-doubtless the above-recently published in a South Carolina paper. Lord Lyons sends Russell both versions, the earlier, from some newspaper copying from the Mcrcury, in a despateh of August 23, the later in one of August 3o. Correspondence, etc., pp. 23-25 (Sessional Papers, I862, LXII. 559-561) ; Brit. and For. St. Papers, LV. 580-582.

${ }^{14}$ This is endorsed: "Letter from Asst. See. of State enelosing two copies of Resolutions as passed and approved. W. H. T. No. 5." 
your letters and will reply to them in person when he can find a moment's leisure from public business. Practically the resolutions and preamble are the same as those published by the Examiner, and will, I hope, be productive of all the acivantages which you predict.

Most truly yours

Wm. M. Browne.

ViI. Telegram.

Wm. H. Trescot

Richmond, [August] 14, I861.

Charleston, S. C.

First proposition maintains right privateering as established by practice and recognized by law [of] nations. Second, neutral flag covers enemy's goods except contraband war. Third, neutral goods except contraband under enemy's flag not liable to seizure. Fourth, blockades to be binding must be effective.

IVilliam M. Browne

Asst. Sec. of State

VIII. Telegram.

William Henry Trescot

Richmond, [August] I4, IS6I.

Charleston, S. C.

Congress has passed and President approved resolutions. First, that Confederate States maintain right of Privateering as established by practice and recognized by law of Nations. Second, neutral flag covers enemy's goods except contraband war. Third, seizure under enemy's flag. Fourth, blockade be binding must be effective.

WM. M. Browne,

Asst. Sec. State

AM. HIST. REV., VOL. XXI11. -54 . 





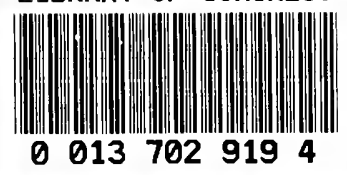

